Volume: 14 Issue: 1 Year: 2017

\title{
The effects of diet and fluid education administered to patients of hemodialysis on some parameters
}

\author{
Selda Arslan ${ }^{1}$ \\ Figen Bekar Tunçalp ${ }^{2}$
}

\begin{abstract}
Background: It is important to assess the effectiveness of education sessions conducted to increase the quality of life of hemodialysis patients, and reduce mortality and complications.

Aim: The study was implemented to evaluate the effect of education given to help hemodialysis patients to adjust to diet and liquid restrictions on the patients' weight, blood pressure, fluid states and laboratory results.
\end{abstract}

Methods: During the study, every week, two sessions of education were given by the researchernurse regarding diet and fluid restriction to patients who received hemodialysis treatment for a period of 8 weeks and parameters were evaluated at the end of the education. The study population consisted of 42 patients who consented to participate in the study between June and December 2014 at the Dialysis Unit of Selcuk University Faculty of Medicine. The study was conducted using the pretest-posttest quasi-experimental research design. Patients aged 18 or above who had been receiving hemodialysis treatment at least for one year, did not have extremity amputation or plegia. The patients' blood pressures, heights, weights and bioimpedance were measured by the researcher-nurse. Average, standard deviation, frequency, number, percentage and paired $t$ test were used in the evaluation of the data. The patients who received treatment were given information about the purpose and method of the study and their consents were received.

Results: It was found that $59.5 \%$ of the patients were female, $47.6 \%$ had primary level of education, $83.2 \%$ were married and $45.2 \%$ were housewives. It was seen that $50 \%$ of the patients who received hemodialysis treatment did not have other chronic diseases, $38.1 \%$ had been receiving hemodialysis for $0-3$ years, $59.5 \%$ knew the amount of fluid they needed to take, $45.2 \%$ received 1500-2000 liters of fluid, 52,4\% did not urinate. Significant changes were observed in the patients' blood pressures before and after the education (systolic p:0,012, diastolic p:0,013) and in their weight when they received dialysis (p:0,000). On the other hand, as far as laboratory data were concerned, significant differences were found before and after the education only in sodium input and output, potassium input and output values, and in extracellular fluid as far as bioimpedance results were concerned.

Conclusion: It was found that significant results were obtained in some parameters as a consequence of the education given to the patients. Given that the best control in long hemodialysis treatments is a decrease in fluid load, patients should definitely be given education emphasizing the importance of diet and fluid restriction. It can be suggested education sessions can be given for longer periods to obtain more significant results.

Keywords: diet and fluid education; hemodialysis; nursing

${ }^{1}$ Corresponding author, Assistant Professor, Ph.D., Faculty of Health Sciences, Nursing Department, University of Selcuk, seldayarali@hotmail.com

${ }^{2}$ M.Sc., Department of Nephrology, Faculty of Medicine, Selcuk University, figen tuncalp@,hotmail.com 
Arslan, S., \& Bekar Tunçalp, F. (2017). The effects of diet and fluid education administered to patients of hemodialysis on some parameters. Journal of Human Sciences, 14(1), 346-354. doi:10.14687/jhs.v14i1.4284

\section{Introduction}

The most frequently applied therapy type is hemodialysis in patients having End Stage Renal Failure. Dialysis therapy recovers uremic symptoms partially but dietary restrictions, obligation to go to dialysis center and situations like hypervolemia and anemia result in great changes in daily life of patients (Rebollo Rubio, Morales-Asencio, Pons-Raventos, \& MansillaFrancisco, 2015:92-93; Li, Jiang, \& Lin, 2014:212; Ovayolu, Uçan, Pehlivan, \& Yıldızgördü, 2007:95). Successful hemodialysis therapy includes fluid restrictions, dietary rules, following drug prescriptions and regularly undergoing hemodialysis for patients. In this therapy method, fluid intake is restricted, daily fluid intakes of patients may be limited by $500-1000 \mathrm{ml}$ when necessary, sodium, potassium $(\mathrm{K})$ and protein intakes are restricted in dietary suggestions (Denhaerynck, et al., 2007:227). Inconsistency in fluid and food intake of patients increases mortality by causing development of malnutrition and impairment of fluid- electrolyte balance (Onofriescu, et al. 2014:112). Fluid and diet planned for patients undergoing hemodialysis must be prepared specifically for the patient by considering clinic symptoms, biochemical values and bio-impedance values. Nurses are in a significant position in bringing behavioral dimension to patients in improvement of clinical results in these important parameters (Denhaerynck, et al. 2007:231). Nurses should increase self-management of patients to improve the adaptation process rather than technical care to improve perceptions and life values in patients undergoing hemodialysis (Li, Jiang, \& Lin, 2014; Lin, Han \& Pan, 2015:2-3).

Professional hemodialysis nursery should aim to provide holistic care to patients in order to attain a better hemodialysis result. However, because the provided care is task oriented, deficiencies occur in the cares required to be managed by patients. Education must be performed accurately and repeatedly to leave the patients and their relatives alone to cope with the hemodialysis which is a long journey (Lin, Han \& Pan, 2015:2-3), and evaluation of repeated educations becomes more crucial (Wong, Chow \& Chan, 2010:276). The importance of compliance to accurate diet and fluid restrictions must be explained to patients and this role must continue as long as the treatment of the disease. The study was conducted in order to evaluate the effect of education which was given to the patients undergoing hemodialysis for eight weeks in order to enable them to adapt to diet and fluid restrictions, on their weights, blood pressure, and fluid situations.

\section{Material and Method}

\section{Study design and participants}

The study was conducted as quasi-experimental in pretest-protest design. Education intended to diet and fluid restrictions for 8 weeks twice per week were given to patients undergoing hemodialysis by researcher dialysis nurse. The population of the study consisted of the patients taking treatment at the Dialysis Unit of Selçuk Medical Faculty between June 2014 and December 2014.

42 patients who accepted to participate in the study were taken in the scope of the study. In the content of the education; education were given by using Manual of Nutrition in Dialysis Patients prepared by Turkish Kidney Foundation and Turkish Society of Nephrology. Consumption of nutrients containing water, salt, potassium, calcium, phosphorus and iron was emphasized in the content of the education.

\section{Inclusion Criteria of the study;}

- Being voluntary to participate in the study

- Being 18 years and over

- Undergoing dialysis treatment for at least 1 year

- Having no psychiatric disorder to prevent communication

- Having no extremity amputation, not being hemiplegic, paraplegic (for the reason of bioimpedance). 
Arslan, S., \& Bekar Tunçalp, F. (2017). The effects of diet and fluid education administered to patients of hemodialysis on some parameters. Journal of Human Sciences, 14(1), 346-354. doi:10.14687/jhs.v14i1.4284

\section{Data Collection Tools}

Descriptive Information Form, Laboratory and bio- impedance results and mercury sphygmomanometer were used in collection of the study data. The questionnaire was prepared in relation with personal characteristics of patients, their hemodialysis and disease related properties, quantity of fluid/ urine, dietary and eating habits and there were 34 questions in total. Blood pressures of the patients were measured by the same research nurse via a standard mercury sphygmomanometer. The questionnaire was formed by considering values required in the clinical routine for laboratory analysis (sodium, potassium, urea, creatinine, calcium, phosphorus, glucose, protein, albumin) and any additional demand was made. Because the bio-impedance device giving information on personal fluid and nutrition situation provides an easy, reliable and objective evaluation opportunity in the study, the Bodystat Quadscan 4000 device was used to evaluate the efficiency of the education. Similarly, height and weight values of the patients were measured by the research nurse.

\section{Data Collection}

The data were collected by performing face-to-face interviews, which lasted approximately 20 minutes between hemodialysis sessions, with patients. Firstly, the questionnaire entitled Before Education was performed to the patients. Monthly blood values were taken from patients before education, the bio-impedance being a noninvasive method was performed in order to calculate fluid index and the education were started. Educations were repeated through face-to-face interviews to each patient for 8 weeks on semi-weekly basis. The questionnaire was performed After Education, blood analysis was evaluated accordingly, and bio-impedance device was used. After data on age, weight and height of patients were entered by the research nurse, measurements were completed in averagely 5 minutes.

\section{Ethical Considerations}

Prior to the study, we obtained a written permission by the Ethical Committee and the written consent of the host institution. Assistance was taken from clinic physicians in interpretation of bio-impedance results.

\section{Data analysis}

The data were analyzed using the Statistical Package for the Social Sciences (SPSS version 20.00). Patients' baseline characteristics of the included patients were summarized using descriptive statistics. Data are presented as numbers, percentages, means, and standard deviations. The mean values of number of steps and other continuous variables at baseline and at the end of 2 months were compared by using paired t-test. A p-value $<0.05$ (two-sided) was considered statistically significant.

\section{Results}

The results of the study which examining the effect of diet and fluid education given to dialysis patients on several parameters were below mentioned. It was found that $59.5 \%$ of the patients were women, educational level of $47.6 \%$ of the patients was primary school, $83.3 \%$ were married, and $45.2 \%$ were housewives (Table 1 ).

Table 1. Baseline characteristics of participants $(n=42)$

\begin{tabular}{|c|c|c|}
\hline Socio-Demographic Characteristics & Number & $(\%)$ \\
\hline Age ( $x \pm s d)$ & \multicolumn{2}{|c|}{$57,52 \pm 12,47$} \\
\hline Gender & & \\
\hline $\begin{array}{l}\text { Woman } \\
\text { Male }\end{array}$ & $\begin{array}{l}25 \\
17\end{array}$ & $\begin{array}{l}59,5 \\
40,5\end{array}$ \\
\hline
\end{tabular}


Arslan, S., \& Bekar Tunçalp, F. (2017). The effects of diet and fluid education administered to patients of hemodialysis on some parameters. Journal of Human Sciences, 14(1), 346-354. doi:10.14687/ihs.v14i1.4284

\begin{tabular}{|l|c|c|}
\hline Education Level & \multicolumn{3}{|c|}{} & 16,7 \\
\hline Illiterate & 3 & 7,1 \\
Literate & 20 & 47,6 \\
Primary school & 2 & 4,8 \\
Middle school & 10 & 23,8 \\
University High School and above & \multicolumn{3}{|}{} \\
\hline Marital status & 35 & 83,3 \\
\hline Married & 7 & 16,7 \\
Single/widowed & \multicolumn{3}{|c|}{} \\
\hline Working status & 19 & 45,2 \\
\hline Housewife & 9 & 33,4 \\
Working & $\mathbf{4 2}$ & $\mathbf{1 0 0}$ \\
Retired &
\end{tabular}

It was found that $50 \%$ of the patients undergoing hemodialysis did not have any other chronic disease, $38.1 \%$ underwent hemodialysis for 1 to 3 years, $59.5 \%$ knew the fluid quantity they should take and $45.2 \%$ took 1500 to 2000 liter of fluid, and $52.4 \%$ of the patients did not have urination (Table 2).

Table 2. Disease-related characteristics of patients

\begin{tabular}{|c|c|c|}
\hline Disease-Related Characteristics & Number & $(\%)$ \\
\hline \multicolumn{3}{|l|}{ Status of chronic disease } \\
\hline No & 21 & 50,0 \\
\hline Hypertension & 8 & 19,0 \\
\hline Diabetes & 6 & 14,3 \\
\hline Diabetest + hypertension & 7 & 16,7 \\
\hline \multicolumn{3}{|c|}{ Time of Starting to Hemodialysis therapy } \\
\hline $0-3$ year & 16 & 38,1 \\
\hline 4-6 year & 7 & 16,7 \\
\hline 7-9 year & 9 & 21,4 \\
\hline $10-12$ year and above & 10 & 23,8 \\
\hline \multicolumn{3}{|c|}{ Status of knowing fluid quantity to be taken between two dialysis sessions } \\
\hline Yes & 25 & 59,5 \\
\hline $\mathrm{No}$ & 17 & 40,5 \\
\hline \multicolumn{3}{|c|}{ Fluid intake quantity between two dialysis sessions } \\
\hline $500-1500$ & 13 & 31,0 \\
\hline $1500-2000$ & 19 & 45,2 \\
\hline 2500 and above & 10 & 23,8 \\
\hline \multicolumn{3}{|c|}{ Status of knowing the significance of fluid restriction } \\
\hline Very important & 16 & 38,1 \\
\hline Important & 19 & 45,2 \\
\hline Somewhat important & 5 & 11,9 \\
\hline Insignificant & 2 & 4,8 \\
\hline \multicolumn{3}{|c|}{ Status of knowing the influence of fluid quantity on tension } \\
\hline Yes & 17 & 40,5 \\
\hline No & 16 & 38,1 \\
\hline Do not know & 9 & 21,4 \\
\hline \multicolumn{3}{|l|}{ Status of ability to urinate } \\
\hline Yes & 20 & 47,6 \\
\hline No & 22 & 52,4 \\
\hline
\end{tabular}


Arslan, S., \& Bekar Tunçalp, F. (2017). The effects of diet and fluid education administered to patients of hemodialysis on some parameters. Journal of Human Sciences, 14(1), 346-354. doi:10.14687/ihs.v14i1.4284

It was found that $11.9 \%$ of the patients were smokers and did not consume alcohol. It was found that $97.6 \%$ of the patients were taking their medication regularly. Significant change was found in blood pressure values of the patients before and after education (systolic p:0.012, diastolic $\mathrm{p}: 0.013)$ and in their weights during entering to dialysis (p:0.000). Before and after the education, significant differences were found only in sodium and potassium values obtained before and after dialysis in laboratory data (Table 3).

Table 3. Blood pressures and blood values of the patients before and after education

\begin{tabular}{|c|c|c|c|c|}
\hline & Before & After & \multicolumn{2}{|c|}{ Test } \\
\hline $\begin{array}{l}\text { Predialysis average systolic blood } \\
\text { pressures }(\mathrm{mmHg})\end{array}$ & $123,88 \pm 18,84$ & $116,76 \pm 18,28$ & t: 2,623 & $\mathrm{p}: 0,012$ \\
\hline $\begin{array}{l}\text { Predialysis average diastolic blood } \\
\text { pressures }(\mathrm{mmHg})\end{array}$ & $74,17 \pm 12,19$ & $70,26 \pm 11,43$ & $\mathrm{t}: 2,608$ & $\mathrm{p}: 0,013$ \\
\hline Predialysis weight $(\mathrm{kg})$ & $72,20 \pm 12,99$ & $71,38 \pm 13,08$ & $\mathrm{t}: 3,904$ & $\mathrm{p}: 0,000$ \\
\hline Hemoglobin value $(\mathrm{g} / \mathrm{dL})$ & $11,57 \pm 1,31$ & $11,86 \pm 1,24$ & $\mathrm{t}:-1,434$ & $\mathrm{p}: 0,154$ \\
\hline Hemaotocrit value $(\%)$ & $36,06 \pm 4,40$ & $36,45 \pm 4,19$ & t:- $-0,554$ & $\mathrm{p}: 0,583$ \\
\hline Pre sodium $(\mathrm{mEq} / \mathrm{L})$ & $137,94 \pm 2,67$ & $135,90 \pm 2,99$ & $\mathrm{t}: 4,399$ & $\mathrm{p}: 0,000$ \\
\hline Post sodium $(\mathrm{mEq} / \mathrm{L})$ & $139,10 \pm 0,99$ & $137,30 \pm 1,49$ & $\mathrm{t}: 4,630$ & $\mathrm{p}: 0,001$ \\
\hline Pre potassium $(\mathrm{mEq} / \mathrm{L})$ & $5,61 \pm 0,82$ & $5,04 \pm 0,79$ & $\mathrm{t}: 4,110$ & $\mathrm{p}: 0,000$ \\
\hline Post potassium $(\mathrm{mEq} / \mathrm{L})$ & $3,73 \pm 0,41$ & $3,34 \pm 0,35$ & $\mathrm{t}: 5,968$ & $\mathrm{p}: 0,000$ \\
\hline Pre urea & $117,66 \pm 27,79$ & $119,40 \pm 32,34$ & $\mathrm{t}:-, 331$ & $\mathrm{p}: 0,742$ \\
\hline Post urea & $32,11 \pm 10,55$ & $32,76 \pm 19,17$ & t:-,234 & $\mathrm{p}: 0,816$ \\
\hline Pre creatinine $(\mathrm{mg} / \mathrm{dL})$ & $8,32 \pm 2,69$ & $8,50 \pm 2,92$ & $\mathrm{t}:-, 517$ & $\mathrm{p}: 0,608$ \\
\hline Post creatinine $(\mathrm{mg} / \mathrm{dL})$ & $2,88 \pm 1,37$ & $2,63 \pm 1,14$ & $\mathrm{t}: 1,533$ & p:0,133 \\
\hline Pre calcium $(\mathrm{mg} / \mathrm{dL})$ & $8,60 \pm 1,00$ & $8,81 \pm 0,72$ & $\mathrm{t}:-1,45$ & $\mathrm{p}: 0,153$ \\
\hline Post calcium (mg/dL) & $8,88 \pm 0,58$ & $8,96 \pm 0,65$ & $\mathrm{t}:-, 530$ & $\mathrm{p}: 0,612$ \\
\hline Phosphorus (mg/dL) & $5,90 \pm 1,67$ & $5,31 \pm 1,25$ & $\mathrm{t}: 1,926$ & p:0,061 \\
\hline Glucose $(\mathrm{mg} / \mathrm{dL})$ & $116,53 \pm 67,34$ & $109,41 \pm 53,91$ & $\mathrm{t}: 0,933$ & $\mathrm{p}: 0,357$ \\
\hline Potassium & $6,89 \pm 0,68$ & $6,81 \pm 0,60$ & $\mathrm{t}: 1,085$ & p:0,284 \\
\hline Albumin $(\mathrm{g} / \mathrm{dL})$ & $3,92 \pm 0,38$ & $3,91 \pm 0,33$ & $\mathrm{t}: 0,213$ & p:0,379 \\
\hline
\end{tabular}

When bio-impedance values of the patients before and after education were examined, it was found that there was significance only in intercellular fluid value (ECW) (Table 4).

Table 4. Bio-impedance values of the patients before and after treatment

\begin{tabular}{|l|c|c|c|}
\hline & Before education & After education & Test \\
\hline FA & $5,07 \pm 1,74$ & $5,62 \pm 3,08$ & t: $-1,025$ p: 0,312 \\
\hline ILNESS Marker & $1,38 \pm 2,82$ & $3,33 \pm 10,79$ & t: $-1,126$ p: 0,268 \\
\hline FFMI & $17,87 \pm 2,64$ & $18,09 \pm 2,42$ & t: $-1,178$ p: 0,247 \\
\hline TBW & $37,83 \pm 6,47$ & $38,56 \pm 7,73$ & t: $-0,717$ p: 0,478 \\
\hline ECW & $17,95 \pm 5,31$ & $16,26 \pm 2,25$ & t: 2,075 p: $\mathbf{0 , 0 4 5}$ \\
\hline ECW\% & $24,81 \pm 6,85$ & $23,56 \pm 2,93$ & t: 1,181 p: 0,246 \\
\hline ICW & $19,76 \pm 6,12$ & $20,52 \pm 4,23$ & t: $-0,929$ p:0,359 \\
\hline
\end{tabular}

FA: phase angle, FFMI: lean mass index, TBW: total body water, ECW: extracellular volume ICW: intracellular volume 
Arslan, S., \& Bekar Tunçalp, F. (2017). The effects of diet and fluid education administered to patients of hemodialysis on some parameters. Journal of Human Sciences, 14(1), 346-354. doi:10.14687/jhs.v14i1.4284

\section{Discussion}

Diet and fluid program applied in patients with chronic renal failure undergoing dialysis plays a crucial role in treatment. Although the patients express that they get bored from making diet continuously and from not having fluid intake rights (Boothby \& Salmon, 2013;84-93). It is reported that the average weight control of patients who can make their self-management in diet and fluid control is better and they get long-term benefits (Tsay, 2003:370). It was found in the study conducted by us for the purpose to evaluate the efficiency of the education that significant changes occurred in initial weights of patients after education ( $\mathrm{p}: 0,000)$. It was found in a study examining the effect of the education given to patients undergoing hemodialysis on weight gain that a significant decrease occurred in initial weight means of patients after education (Kurt, et al., 2012:40-43). Repeated education was given in order to enhance dietary adaptation in an experimental study conducted by using learning model of bandura, it was found that at the end of six months the weight gain in the trained group decreased compared to the untrained group (Tsay, 2003:370).

Blood pressure, urine amount and weight gain between two dialysis sessions are reliable clinical symptoms in adjustment of fluid intake (Y1lmaz, et al., 2014:270-272) but this may cause misinterpretation sometimes. Therefore, it can be useful to use bio-impedance devices giving information about intracellular, extracellular and total body fluids, ensuring more reliable, fast and objective evaluation and having advantage as being non-invasive (Kotanko, Levin \& Zhu 2008:808-809; Hür, et al., 2011:236). Although there are numerous causes of hypertension being one of the undesirable clinical results in patients with end-stage renal failure, one of the prominent causes in dialysis patients is fluid loading (D'Amico \& Locatelli, 2002; Tekçe, Aktaş \& Kürşat 2012:178; Yllmaz, et al., 2014:270-272). In the present study, a significant difference was found in systolic and diastolic blood pressure before and after education. In a study where blood pressure was evaluated with regard to salt restrictions, it was observed that the average systolic blood pressure during dialysis were significant compared to those determined before the education but that no significant change occurred between average diastolic blood pressures during dialysis before and after education (Kurt, et al., 2012:40-43), in 2-month study of Barnett that education did not make any effect on blood pressure (Barnett, Li Yoong, Pinikahana \& SiYen, 2008:303). It was indicated in the literature that the best blood pressure control in long hemodialysis therapy is the decrease in fluid load (Charra, ve ark., 1999; D'Amico \& Locatelli, 2002:8, Aktaş \& Kürşat, 2012:177-180; Yılmaz et al., 2014:270-272). In the present study, it was found that the education given on salt and fluid control was effective in ensuring blood pressure control and the significant difference arising in extracellular volume values supported these results. Follow-up of the patients after the education given by doctors and nurses, and evaluation of the results have a crucial importance in patient follow-up.

The accepted blood $\mathrm{K}$ levels in patients undergoing hemodialysis were in the range of 3.5$5.5 \mathrm{mEq} / \mathrm{L}$. When the effect of the education on the blood values was evaluated in the present study, it was found that there was significance only in sodium and potassium values obtained before and after dialysis. Although the potassium values were close to these limits in the present study, it was detected that the values decreased in respect to education status and dialysis exit status. In a systematic study in which hemodialysis inconsistency was evaluated, it was noted that the status of inconsistency to potassium varied from $2 \%$ to 39\% (Denhaerynck, et al., 2007: 227). In the study conducted by Yöntem and Odabaş; the $\mathrm{K}$ values of the patients were found as $5.03 \mathrm{mEq} / \mathrm{L}$ before dialysis and $3.68 \mathrm{mEq} / \mathrm{L}$ after dialysis. In addition to the studies revealing that there was no significant difference between $\mathrm{K}$ values before and after hemodialysis and between groups, there are also studies indicating that potassium levels of patients who could maintain control in their diet are lower and that they take lower quantity of fluid between two dialysis sessions (Zrinyi, et al., 2003:1871; Çinar ve ark. 2005). These results revealing high values of $\mathrm{K}$ showed that the expected $\mathrm{K}$ values before dialysis decreased when patients abide with their regular diet and completion and keeping longer of duration of dialysis is efficient in cleaning values obtained after dialysis. 
Arslan, S., \& Bekar Tunçalp, F. (2017). The effects of diet and fluid education administered to patients of hemodialysis on some parameters. Journal of Human Sciences, 14(1), 346-354. doi:10.14687/jhs.v14i1.4284

When sodium values of the patients were examined in the study, it was found that a significant change occurred in sodium values before and after dialysis following the education and a significant decrease occurred in extracellular volume. The literature on the controlling of blood pressure in patients undergoing hemodialysis through diet containing low amount of sodium is clear (Tekçe, Aktaş \& Kürşat, 2012:180). The increase in sodium results in an increase in blood pressure by causing an increase in extracellular volume (Wilson, Shah \& Nissenson 2000:262). Thus, keeping the extracellular volume within normal limits is important for the blood pressure balance. Significance of sodium values of the patients can be explained by fact that patients undergoing dialysis became sensitive due to continuous reminder related to salt restriction. In a study in which the effect of diet education on laboratory results was evaluated and pretest-posttest information test was applied; educations of 20 to 30 minutes per month were given to the patients, its effect on serum calcium and phosphorus levels was examined and it was found at the end of the study that the knowledge level of the trained group was higher compared to untrained group and serum phosphorus and calcium levels decreased significantly at the end of 6 months (Ford, Pope, Hunt \& Gerald, 2004:42-43). The data were within these limits in the study, but the failure of determining significance may be explained by shortness of the duration of education.

The fact that serum albumin value was lower than $4 \mathrm{~g} / \mathrm{dL}$ and that serum creatinine and urea levels were low in patients without residual, are evaluated as late indication of malnutrition in patients undergoing dialysis (Oğuzhan \& Utaş 2009:26), also lower albumin values before hemodialysis can arise depending on hypervolemia in patients. It was indicated by the Turkish Society of Nephrology that serum albumin level was between $3.5-4 \mathrm{gr} / \mathrm{dl}$ in $50.1 \%$ of totally 39171 HD patients in the period between 1996 and 2008. Additionally, it was found in the study that albumin value in patients was close to 4 , no difference was found between albumin value and education efficiency. In a study in which diet control for 12 months was provided; when the patients with albumin level below $3.7 \mathrm{~g} / \mathrm{dL}$ were compared with control group, it was found that serum albumin levels of patients increased. In the results of the study, albumin levels of patients were observed in normal range compared to CRF patients, it was thought that it stemmed from taking care to food stuff containing protein and the fact that no significant results were obtained before and after education was explained by requirement of longer term follow-up for change in albumin level.

It was found in the study that phosphorus values decreased but no significant difference was found. In consequence of a study in which the factors affecting the success of phosphorus binding medications were examined as experimental and by using interview technique, it was stated that phosphorus levels of patients undergoing hemodialysis should be examined on monthly basis and education and compliance may help the efficiency of treatment of patients undergoing hemodialysis (Agus, 2014:337). Phosphorus restriction in patients undergoing dialysis result in an increase in needs for calcium because of deficiency in vitamin D. Low $(<9.0 \mathrm{mg} / \mathrm{dl})$ and high $(>10.0 \mathrm{mg} / \mathrm{dl}$ ) calcium levels were found to be related to increased mortality (Miller, et al., 2010:409). Educations should be given in consideration of individual differences as calcium use in patients undergoing dialysis can cause serious hypercalcemia.

Bio-impedance is one of the preferred methods in evaluation of volume status of HD patients because it is simple and cost-effective. It is known that ECW and ECW\% reflect hypervolemia. Fluid excess may be estimated by obtaining ECW from TBW through bioimpedance (Kotanko, et al., 2008:808-809). Significance was found only in ECW in the study. Bioimpedance results are important to evaluate the volume status of the patients and to plan nursing interventions accordingly. Lack of adequate changes in results made us think that this because the evaluation was made in a short period like 8 weeks, the education levels of patients were low, they were not conscious about the given education, they forgot the education or could not put it into practice. Hemodialysis nurses being in continuous contact with this patient group have important duties and responsibilities. 
Arslan, S., \& Bekar Tunçalp, F. (2017). The effects of diet and fluid education administered to patients of hemodialysis on some parameters. Journal of Human Sciences, 14(1), 346-354. doi:10.14687/jhs.v14i1.4284

\section{Conclusions}

Significant differences were found in the following values before and after education in the study;

- values of blood pressure (systolic p:0.012, diastolic p:0.013)

- weight during undergoing dialysis (p:0.000)

- values of sodium and potassium before and after dialysis

- ECW value.

In line with these results; it can be suggested that nurses detect deficiencies in diet practices of the patients in order to facilitate diet compliance in patients undergoing hemodialysis, provide diet education regularly and these parameters which can be continuously changeable are followed up. Bio-impedance results are important to evaluate the volume status of the patients and to plan nursing interventions accordingly.

Limitations of the Study: The limitation of the study was the relatively small sample, which consisted of individuals who attended Dialysis Unit of Selçuk Medical Faculty Hospital. For this reason, these findings cannot be generalized to the broader community based on this study alone.

Acknowledgement: We would like to thank Associate Professor Gülperi Çelik who supported the study.

\section{References}

Agus, L. S., Effendi, I., \& Abdillah, S. (2014). Influence of the use of phosphate binders on serum levels of calcium phosphate in patients with chronic kidney disease undergoing hemodialysis: A retrospective and prospective study Saudi Pharmaceutical Journal, 22, 333-337.

Barnett, T., Li Yoong, T., Pinikahana, J., \& Si-Yen, T. (2008). Fluid compliance among patients having haemodialysis: Can an educational programme make a difference? J Adv Nurs, 61, 300-306.

Boothby, M. R. K., \& Salmon P. (2013). Öz Yeterlilik Ve Hemodiyaliz Tedavisi: Nitel Ve Nicel Bir Yaklaşım, Türk Psikiyatri Dergisi, 24(2), 84-93.

Charra, B., Chazot, C., \& Jean, G., (1999). Laurent, G. Long, slow dialysis. Miner Electrolyte Metab, 25, 391-396.

D'Amico, M., \& Locatelli, F. (2002). Hypertension in dialysis: pathophysiology and treatment. J Nephrol,15(4), 438-45.

Denhaerynck, K., Manhaeve, D., Dobbels, F., Garzoni, D., Nolte, C., \& De Geest, S. (2007). Prevalence and consequences of nonadherence to hemodialysis regimens. Am J Crit Care, 16(3), 222-35.

Elmas, A., Erbay, S.E., Tuğrul, A., Şengül, E., \& Bülbül, F. (2012). Hemodiyaliz Hastalarında Beslenme Bilgi Düzeyi ile Klinik ve Laboratuar Bulguları Arasındaki İlişki, Kocaeli Tıp Dergisi, 3, 23-26.

Ford, C. J., Pope, J. F., Hunt, A. E., \& Gerald, B. (2004). The effect of diet education on the laboratory values and knowledge of hemodialysis patients with hyperphosphatemia, Journal of Renal Nutrition, 14(1), 36-44.

Griva, K., Mooppil, N., Seet, P., Krishnan, D. S., James, H., \& Newman, S. P. (2011). The NKFNUS hemodialysis trial protocol - a randomized controlled trial to determine the effectiveness of a self management intervention for hemodialysis patients. BMC Nephrology, 12, 4.

Hür, E., Güngör, Ö., Aşçı, G., Demirci, M.S., Kayıkçığlu, L.M., Kahvecioğlu, S. ve ark. (2011). Hemodiyaliz Hastalarında Hipervoleminin Gösterilmesinde Biyoimpedans Spektroskopinin Yeri. Turk Neph Dial Transpl, 20 (3), 235-240. 
Arslan, S., \& Bekar Tunçalp, F. (2017). The effects of diet and fluid education administered to patients of hemodialysis on some parameters. Journal of Human Sciences, 14(1), 346-354. doi:10.14687/jhs.v14i1.4284

Wilson. J, Shah T., \& Nissenson A. R (2000). Role of sodium and volume in the pathogenesis of hypertension in hemodialysis. Seminars in Dialysis, 17, 260-264.

Kotanko, P., Levin, N. W., \& Zhu, F. (2008). Current state of bioimpedance technologies in dialysis. Nephrol Dial Transplant, 23, 808-812.

Kurt, Y. T., Erdem, E., Kaya, C., Karataş, A., \& Arık, N. (2012). Hemodiyaliz Hastalarına Verilen Eğitimin Kan Basıncı ve Kilo Alımına Etkisi. Turk Neph Dial Transpl, 21 (1), 39-44.

Li, H., Jiang, Y., \& Lin, C. C. (2014). Factors associated with self-management by people undergoing hemodialysis: A descriptive study. International Journal of Nursing Studies, 51 (2) 208-216.

Lin, C. C., Han, C. Y., \& Pan, I. J. A. (2015). Qualitative Approach of Psychosocial Adaptation Process in Patients Undergoing Long-term Hemodialysis. Asian Nursing Research, 1-7.

Miller, J. E., Kovesdy, C. P., Norris, K. C., Mehrotra, R., Nissenson, A. R., Kopple, J. D., \& Kalantar-Zadeh, K., (2010). Association of cumulatively low or high serum calcium levels with mortality in long-term hemodialysis patients. Am. J. Nephrol, 32 (5), 403-413.

Moissl, U. M., Wabel , P., Chamney, P. W., Bosaeus, I, Levin, N. W., Bosy-Westphal, A., Korth, O, Müller, M. J., Ellegård, L., Malmros, V., Kaitwatcharachai, C., Kuhlmann, M. K., Zhu, F., \& Fuller, N. J. (2006). Body fluid volume determination via body composition spectroscopy in health and disease. Physiol Meas, 27(9), 921-33.

Oğuzhan, N., \& Utaş, C. (2009). Kronik Böbrek Yetmezliğinde Malnutrisyon. Turkiye Klinikleri. J Nephrol-Special Topics, 2(2), 26-33.

Onofriescu, M., Hogas, S., Voroneanu, L., Apetrii, M., Nistor, I., Kanbay, M., \& Covic, A. C. (2014). Bioimpedance-guided fluid management in maintenance hemodialysis: a pilot randomized controlled trial. Am J Kidney Dis, 64(1), 111-8.

Ovayolu, N., Uçan, Ö., Pehlivan, S., \& Yıldızgördü, E. (2007). Hemodiyaliz Hastalarının Tedaviye ve Diyete Uyumları İle Bazı Kan Değerleri Arasındaki İlişki. Fırat Sağlık Hizmetleri Dergisi, 2(4), 94-100.

Rebollo Rubio, A., Morales-Asencio, J. M., Pons-Raventos, M. E., \& Mansilla-Francisco, J. J. (2015). Review of studies on health related quality of life in patients with advanced chronic kidney disease in Spain. Nefrologia. Jan 21;35(1):92-109. doi:10.3265/Nefrologia.pre2014.Jul.12133.

Tekçe, H., Aktaş, G., \& Kürşat, S. (2012). Son Dönem Böbrek Yetmezliğinde Hipertansiyon ve Patogenezi; Sodyum ve Volüm Kontrolünün Önemi, Abant Medical Journal, 1(3)

Tsay, S.L. (2003). Self-efficacy training for patients with end-stage renal disease. JAdv Nurs, 43, 370-375.

Yılmaz, Z., Yıldırım, Y., Yılmaz Aydın, F., Aydın, E., Kadiroğlu, A. K., Yılmaz, M. E., \& Acet, H. (2014). Evaluation of fluid status related parameters in hemodialysis and peritoneal dialysis patients: Clinical usefulness of bioimpedance analysis Medicina, 50(5), 269-274.

Yöntem, M., \& Odabaş, G. (2009). Kütahya bölgesinde bulunan hemodiyaliz hastalarının bazı biyokimyasal parametrelerinin değerlendirilmesi. DPU Fen Bilimleri Dergisi, 19, 7-14.

Wong, F. K. Yuet, Chow, S. K., \& Chan, T. M. (2010). Evaluation of a nurse-led disease management programme for chronic kidney disease: A randomized controlled trial. Int J of Nurs Stud, 47, 268-278.

Zrinyi M, Ju hasz M, Balla J et al. (2003). Dietary self-efficacy: Determinant of compliance behaviours and biochemical outcomes in haemodialysis patients. Nephrol Dial Transplant, 18, 1869-73. 